\title{
ZAGOSPODAROWANIE RODZINNYCH OGRODÓW DZIAŁKOWYCH (ROD) NA PRZYKŁADZIE ROD IM. JÓZEFA CHOCISZEWSKIEGO W POZNANIU
}

\author{
THE DEVELOPMENT OF FAMILY ALLOTMENT GARDENS (FAG) \\ (A CASE STUDY OF JÓZEF CHOCISZEWSKI FAG IN POZNAŃ)
}

DOI: $10.25167 / \mathrm{sm} 2017.025 .08 \quad$ s. $133-147$

\begin{abstract}
ABSTRAKT: Współcześnie ogrody działkowe stanowią utrapienie wielu urbanistów. Najpoważniejszymi zarzutami stawianymi ogrodom działkowym są brak dostępności dla lokalnych społeczności oraz bardzo dyskusyjna estetyka wielu działek, która wynika z dużej swobody w ich sposobie zagospodarowania. Rodzinny ogród działkowy (ROD) im. Józefa Chociszewskiego w Poznaniu zaliczany jest do najstarszych poznańskich ogrodów. Cechą charakterystyczną są wybudowane przez jeńców wojennych jednolite altanki, które stanowią bardzo ważny element kompozycji przestrzennej tego ogrodu. Praca ma na celu przedstawienie aktualnych tendencji w sposobie zagospodarowania działek w rodzinnych ogrodach działkowych na przykładzie ROD im. Józefa Chociszewskiego w Poznaniu. Wyniki inwentaryzacji 25 losowo wybranych działek dowiodły duże zróżnicowanie w tym względzie. Zdecydowaną większość działek charakteryzuje duży udział powierzchni trawnika do całkowitej powierzchni działek oraz mały - powierzchni przeznaczonej pod uprawy warzywne. Fakt ten świadczy o zmianie funkcji ogrodów działkowych z użytkowych na rekreacyjno-wypoczynkowe.
\end{abstract}

SŁOWA KLUCZOWE: ogrody działkowe, prawo działkowe, rekreacja, działka, zieleń miejska, Poznań

ABSTRACT: Nowadays, allotment gardens are the bane of many urban planners. The biggest allegations against allotment gardens are the lack of accessibility for local community and highly controversial aesthetics of many plots, which results from the large freedom in ways of their development. The Józef Chociszewski Family Allotment Garden (FAG) in Poznan is one of the oldest allotment complexes in Poznań. Its characteristic feature are the uniform bowers built by prisoners-of-war, which make a very important element of the spatial composition of this complex. The paper aims to present current trends in the way the plots are developed in family allotment gardens, using the example of Józef Chociszewski FAG in Poznań. The results of an inventory of 25 randomly selected plots showed a high diversity in the way of their management. The vast majority of plots have a large share of lawn area in proportion to the total area of the plots and a low share of the area designed for growing vegetables. This fact indicates a change in the allotment gardens function from productive to leisure-recreational one.

KEY WORDS: allotment gardens, allotment law, recreation, garden plots, urban green, Poznań

* Uniwersytet Przyrodniczy w Poznaniu, Wydział Ogrodnictwa i Architektury Krajobrazu, Katedra Botaniki, ul. Wojska Polskiego 71C, 60-625 Poznań, e-mail: dominika.dymek@up.poznan.pl, lbednorz@ up.poznan.pl 


\section{Wprowadzenie}

Obecnie mieszkańcy miast stanowią ponad połowę ludności świata. Raport przygotowany przez Departament Spraw Ekonomicznych i Społecznych ONZ (DESA) jednoznacznie wskazuje, że tempo urbanizacji w skali świata wzrasta nieubłaganie. W połowie XX w. mieszkańcy miast stanowili jedynie 30\% światowej populacji. Szacuje się, że w 2050 r. odsetek ten przekroczy $60 \%$. Zgodnie z raportem „Towards an urban agenda in European Union" (1997) miasta powinny zapewniać swoim mieszkańcom zaspokojenie wszelkich potrzeb związanych z pracą, wypoczynkiem oraz rekreacją i uwzględniać zrównoważony rozwój, który stanowi podstawowy czynnik determinujący jakość życia w mieście. Konieczność zintegrowanego podejścia do przestrzeni miejskich uwzględniającego zarówno aspekty społeczne, ekonomiczne, jak i ekologiczne postulują także Zielona Karta Miast (1990) oraz Raport Miast Zrównoważonych (1996).

Podstawowym kryterium rozwoju lokalnego, rozumianego jako „prowadzenie działań na rzecz rozwoju gospodarczego i społecznego danej jednostki terytorialnej (miasta, gminy) z wykorzystaniem jej zasobów, z uwzględnieniem potrzeb mieszkańców oraz przy ich udziale w podejmowanych działaniach" (Parysek 1995, s. 37), jest zadowolenie mieszkańców i zaspokojenie postrzeganych przez nich potrzeb. To społeczności lokalne są głównym podmiotem, a zarazem animatorem szczególnego procesu zmian określanego jako rozwój lokalny (Groeger 2016). Według Andreasa Billerta (2013) kultura w miastach stanowi odzwierciedlenie określonych sposobów życia, mieszkania i pracy ich mieszkańców, którzy nadają konkretnym przestrzeniom wartości symboliczne, dzięki czemu stają się one swojskie, bliskie i przyjazne. W ten sposób wykształca się lokalna tożsamość danej społeczności, która stanowi niezbędny element każdej przestrzeni miejskiej, gdyż „w przeciwnym razie miasto jest w najlepszym wypadku kulisami temporalnych «eventów» ${ }^{1}$, w najgorszym staje się slumsem" (Billert 2013, s. 20).

Początki ogrodnictwa działkowego sięgają pierwszej połowy XIX w. Pierwsze ogrody tego typu powstawały w Wielkiej Brytanii i Niemczech jako pomoc socjalna dla ubogich rodzin robotniczych. Z czasem nadrzędną funkcją ogrodów stało się zapewnienie zdrowego miejsca wypoczynku i rekreacji, duży nacisk kładziono także na kształtowanie postaw społecznych i umiejętności współpracy (Pawlikowska-Piechotka 2010). W Polsce, podobnie jak na Zachodzie, podstawą tworzenia ogrodów działkowych były korzyści ekonomiczne wynikające z uprawy roślin, a także walory: społeczne, zdrowotne, moralno-wychowawcze, materialne i estetyczne (Wilczyński 1927). Idea ogrodnictwa działkowego doskonale wpisywała się w cele realizowane przez miniony ustrój społeczno-gospodarczy - socjalizm, który pozostawił po sobie bardzo rozległe tereny rodzinnych ogrodów działkowych widoczne w strukturze funkcjonalno-przestrzennej wielu polskich miast (Szkup 2013).

\footnotetext{
${ }^{1} \mathrm{Z}$ ang. - czasowych zdarzeń.
} 
Obecnie w Polsce istnieje niespełna 5 tys. ogrodów działkowych, które składają się z prawie 1 mln działek, a ich łączna powierzchnia wynosi ponad 43 tys. ha (dane GUS z 2014 r.). Ze względu na swoje położenie - centralne lub w pobliżu dróg o dużym natężeniu ruchu - dalsza egzystencja ogrodów działkowych w wielu miastach staje się dyskusyjna lub wręcz niemożliwa (Mierzejewska 2001). Ponadto ogrody działkowe, zajmując bardzo atrakcyjne inwestycyjnie tereny miejskie, stanowią zmorę wielu urbanistów i planistów, co w dalszej kolejności prowadzi do stopniowego ich wypierania z polskiego krajobrazu kulturowego. Analiza danych statystycznych przeprowadzona przez Magdalenę Szczepańską i in. (2016) wykazała, że w latach 2003-2013 miał miejsce spadek liczby ROD we wszystkich województwach Polski. Najpoważniejszymi zarzutami stawianymi ogrodom działkowym są brak dostępności dla lokalnych społeczności (Szczęsny, Kimic 2012) oraz bardzo dyskusyjna estetyka wielu działek (Romanowski 2012, Dymek 2015), która wynika z dużej swobody w ich sposobie zagospodarowania.

Mimo ograniczonej dostępności, która klasyfikuje ogrody działkowe jako przestrzenie o charakterze półprywatnym, zdecydowanie odgrywają one pozytywną rolę w urbanistyce i ekosystemie miast i osiedli, a także sprzyjają podnoszeniu jakości życia swoich użytkowników oraz ich gości. Specyficzny program funkcjonalny sprawia, że nie mogą być one zastąpione zielenią ogólnodostępną (Kosmala, Kamińska 2013). Szczególne znaczenie ROD polega na: kształtowaniu środowiska, ochronie i zachowaniu składników przyrody, prowadzeniu i propagowaniu działalności ekologicznej oraz prowadzeniu szerokiej działalności na rzecz społeczności lokalnej (Szczepańska et al. 2016). Obecnie ze względu na złagodzenie zapisów regulaminu dotyczących sposobu zagospodarowania działek w ROD zauważalna jest wyraźna tendencja polegająca na stopniowym wypieraniu tradycyjnej funkcji uprawowej przez rekreacyjno-wypoczynkową, która wskazuje na pojawienie się nowej grupy użytkowników szukających w ogrodach wyciszenia i odpoczynku, a niekoniecznie ciężkiej pracy przy uprawie warzyw czy owoców. Dawne restrykcyjne normy dotyczące maksymalnej dozwolonej powierzchni trawnika skutecznie blokowały rozwój działek jako przestrzeni wypoczynku i rekreacji. Obecnie nie obowiązują żadne tego typu zapisy, dzięki czemu każdy działkowiec może sam decydować o tym, w jaki sposób będzie użytkował swoją działkę, stanowi ona więc wierne odzwierciedlenie jego aktualnych potrzeb.

\section{Zagospodarowanie działek dawniej i dziś}

Pierwszym dokumentem normującym sposób gospodarowania działkami przez ich użytkowników była Tymczasowa instrukcja ogłoszona przez Związek Towarzystw Ogrodów i Osiedli Działkowych (TOiOD) w 1947 r. (Pawlikowska-Piechotka 2010). Bardzo szczegółowo określała ona zasady tworzenia, zagospodarowywania i użytkowania działek. Zalecano wytyczanie prostokątnych działek o powierzchni ok. $300 \mathrm{~m}^{2}$ $(15 \mathrm{~m} \times 20 \mathrm{~m})$. Dostępne były gotowe projekty altanek o maksymalnej powierzchni 
$20 \mathrm{~m}^{2}$, które pełniły funkcje składzików na narzędzia i ochrony przed deszczem. Obowiązywał całkowity zakaz stawiania budynków mieszkalnych oraz inwentarskich, np. kurników i chlewików. Dopuszczano natomiast budowę elementów małej architektury służących rekreacji, a także elementów zabawowych dla dzieci. 16 stycznia 1953 r. opracowano regulamin pracowniczych ogrodów działkowych, który jeszcze dokładniej instruował działkowców odnośnie do zagospodarowania ich działek (Pawlikowska-Piechotka 2010). Ustawa z dnia 9 marca 1949 r. o pracowniczych ogrodach działkowych przewidywała powierzchnię pojedynczych działek mieszczącą się w zakresie 100-500 m². Oprócz wcześniej wspomnianego modułu $15 \times 20$ m dopuszczano także $16 \times 25 \mathrm{~m}$. Wymiary te uzasadniano możliwością racjonalnego wykorzystania przestrzeni działek, które w pierwszej kolejności miały służyć prowadzeniu upraw ogrodniczych. Przed założeniem ogrodu sporządzano tzw. plan regulacyjny, który precyzyjnie określał lokalizację altan, kształty dachów, sposób grodzenia działek, a także rozmieszczenie większych drzew. Typowy układ przestrzenny pojedynczej działki kształtował się następująco: infrastruktura - 20\% ogólnej powierzchni działki, w tym budynki gospodarcze $\left(9 \mathrm{~m}^{2}\right)$, alejki $\left(26 \mathrm{~m}^{2}\right)$, plac na zbiornik wodny $\left(1 \mathrm{~m}^{2}\right)$ i plac gospodarczy $\left(3 \mathrm{~m}^{2}\right)$; sad - 5-10\% ogólnej powierzchni działki; warzywnik - 20-30\% ogólnej powierzchni działki; rośliny ozdobne - 5-10\% ogólnej powierzchni działki oraz część wypoczynkowa łącznie z altaną stanowiącą 5-10\% ogólnej powierzchni działki (Roskosz 1968). Taki podział wyraźnie determinował użytkowe przeznaczenie działek. Zmiany nadeszły wraz z nową ustawą z dnia 6 maja 1981 r. o pracowniczych ogrodach działkowych. 29 października 1981 r. znowelizowano także regulamin pracowniczego ogrodu działkowego. Szczegółowo określone zostało wyposażenie każdej działki. Ponadto każdy działkowiec zobowiązany był do przedłożenia zarządowi ogrodu projektu zagospodarowania swojego ogródka przed rozpoczęciem jakichkolwiek prac. Publikowano liczne poradniki i albumy zawierające gotowe schematy zagospodarowania działek (rysunek 1). Obowiązywały szczegółowe wytyczne dotyczące lokalizacji poszczególnych elementów wyposażenia (rysunek 2). Budowa altany była możliwa tylko po uzyskaniu zgody zarządu ogrodu, który wymagał wcześniejszego przedłożenia szczegółowego projektu uwzględniającego jej lokalizację.

Współcześnie, z powodu tanich i coraz łatwiej dostępnych owoców i warzyw, z ogrodów działkowych znikają grządki warzywne i kwatery sadownicze. Ich miejsce zastępuje trawnik, który sprzyja rekreacji. Często można w nim dostrzec pozostałości obrzeży po dawnym warzywniku. W ten sposób w ogrodach przybywa tzw. głodnych działek, na których nie prowadzi się żadnych upraw, a służą one jedynie wypoczynkowi (Worytkiewicz 2012). Wśród elementów stanowiących aktualne wyposażenie ogrodu działkowego widać wyraźnie tendencję do rekreacyjnego wykorzystania przestrzeni działek (Długozima 2012). Wynika to z faktu, iż obecnie obowiązujące prawo działkowe daje dużo większą swobodę ich użytkownikom. Do niedawna obowiązywało rozgraniczenie maksymalnej powierzchni altan w zależności od lokalizacji ogrodu. Obecnie powierzchnia zabudowy altany dla miejskich i podmiejskich ogrodów działkowych została ujednolicona i wynosi $35 \mathrm{~m}^{2}$. Taka wielkość altan, odpowiadająca rozmiarom 
kawalerek, zapewnia komfortowe warunki, przez co sprzyja rekreacyjnemu wykorzystaniu działek (Dymek 2014).

Pomimo wyraźnej tendencji do zmiany charakteru działek z użytkowych na rekreacyjne nadal wiele z nich posiada grządki warzywne czy małe sady. Sytuacja ta nie wynika, jak dawniej, ze względów ekonomicznych. Ma ona związek z coraz modniejszym ostatnimi czasy ogrodnictwem ekologicznym i zdrowym stylem życia (Dymek 2015).

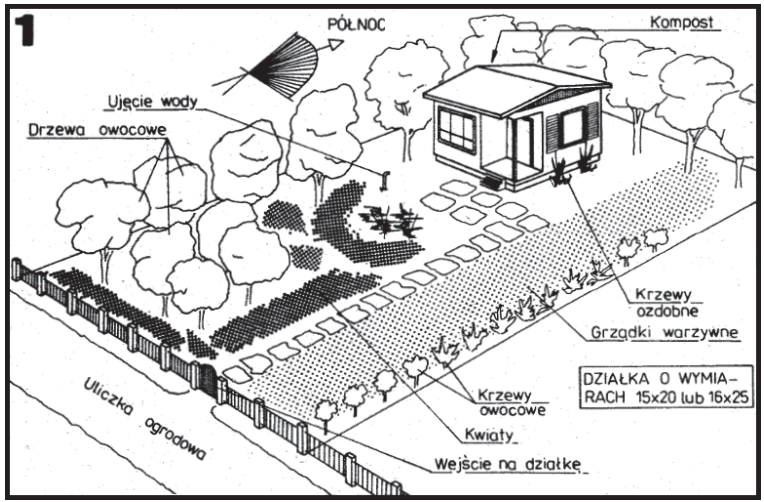

Rys. 1. Przykładowe zagospodarowanie standardowej działki

Źródło: http://www.wypoczynek1986dg.strefa.pl/zasady.html (dostęp 12 listopada 2016).

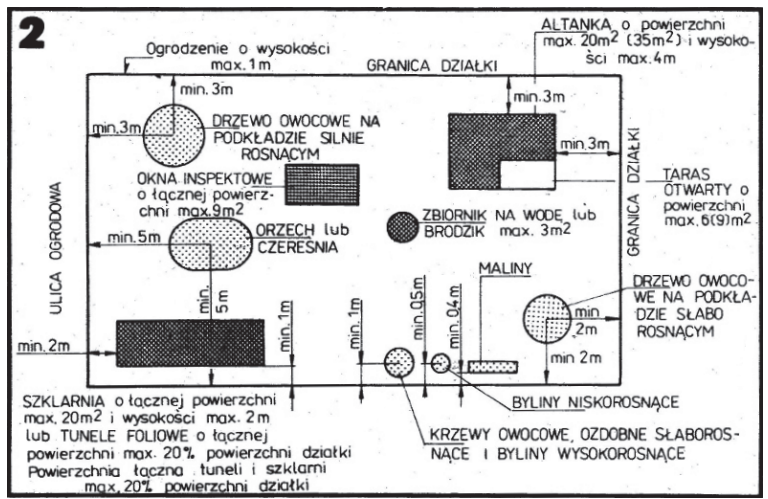

Rys. 2. Zasady zagospodarowania działek w ogrodach działkowych

Źródło: Jak w rysunku 1.

\section{Cel i metoda badań}

Praca ma na celu przedstawienie współczesnych tendencji w sposobie zagospodarowania działek w rodzinnych ogrodach działkowych (ROD) będących odzwierciedleniem potrzeb miejskich społeczności lokalnych, na przykładzie ROD im. Józefa 
Chociszewskiego w Poznaniu. Szczególną uwagę położono na określenie aktualnego znaczenia funkcji użytkowej i rekreacyjnej działek w ROD.

Badania przeprowadzono w maju i czerwcu 2014 r. Polegały one na inwentaryzacji 25 wybranych działek z 244 (10,25\%) ROD im. Józefa Chociszewskiego w Poznaniu. Poligony badawcze wybrano metodą nielosowego doboru przypadkowego. Pomiary objęły dwie grupy elementów: ożywione i nieożywione. Wśród elementów ożywionych brano pod uwagę: powierzchnię przeznaczoną pod uprawy warzywnicze, sadownicze, rośliny ozdobne oraz trawnik. W grupie elementów nieożywionych badano: powierzchnie przeznaczone pod zabudowę (np. altanki i budynki gospodarcze ${ }^{2}$ ), komunikację (ścieżki utwardzone i nieutwardzone), przestrzenie niewykorzystane, czyli nieużytki, gratowisko ${ }^{3}$ oraz inne (np. WC, piaskownice, baseny, oczka wodne). Do pomiarów posłużyła taśma miernicza o długości $30 \mathrm{~m}$ oraz kółko pomiarowe. Wyniki zestawiono z powierzchniami całkowitymi poszczególnych działek, które pozyskano z Zarządu ROD im. Józefa Chociszewskiego w Poznaniu.

\section{Historia ROD im. Józefa Chociszewskiego w Poznaniu}

Rodzinny ogród działkowy im. Józefa Chociszewskiego zlokalizowany jest w Poznaniu przy ulicy Grochowskiej w dzielnicy Grunwald (rysunek 3). Zaliczany jest do najstarszych poznańskich ogrodów. Powstał jesienią 1923 r. z inicjatywy grona miłośników przyrody oraz pracowników m.in. poczty i kolei. Pierwotnie obejmował on nieużytki pomiędzy ulicami: Chociszewskiego, Arciszewskiego, Palacza i Pogodną, należące do miasta Poznania, na których wytyczono 500 działek, każda o powierzchni ok. $300 \mathrm{~m}^{2}$ (Lisiewicz 2001).

W czasie drugiej wojny światowej na terenie ogrodu wprowadzono całkowity zakaz wstępu dla Polaków, a działki zostały przekazane napływającej ludności niemieckiej. Nowi zarządcy przeprowadzili reorganizację ogrodu. Opracowano jego nowy plan, przy wdrażaniu którego zaangażowano jeńców wojennych. Wytyczono nowe działki, na których wybudowano istniejące do dziś jednolite altanki (Lisiewicz 2001). Stanowią one istotny element kompozycyjny ogrodu, który zdecydowanie wyróżnia go na tle innych ogrodów działkowych.

Po zakończeniu wojny prawowici użytkownicy odzyskali swoje działki. Od czasu do czasu miały miejsce doniesienia o odnalezionych niewypałach, m.in. na działkach nr 234 i 235. W 1951 r. prezesem ogrodu został Roman Redeman. Za jego kadencji do ogrodu przyłączono 45 działek miejskich zlokalizowanych przy ulicy Pogodnej, tereny po byłej żwirowni oraz teren boiska nieistniejącego już klubu sportowego Korona Poznań. Wybudowano funkcjonujący do dziś budynek zarządu. Cyklicznie organizowano

\footnotetext{
${ }^{2}$ Mierzone po obrysie zewnętrznym.

${ }^{3}$ Miejsce składowania niepotrzebnych przedmiotów lub materiałów, które w przyszłości mogą okazać się użyteczne.
} 


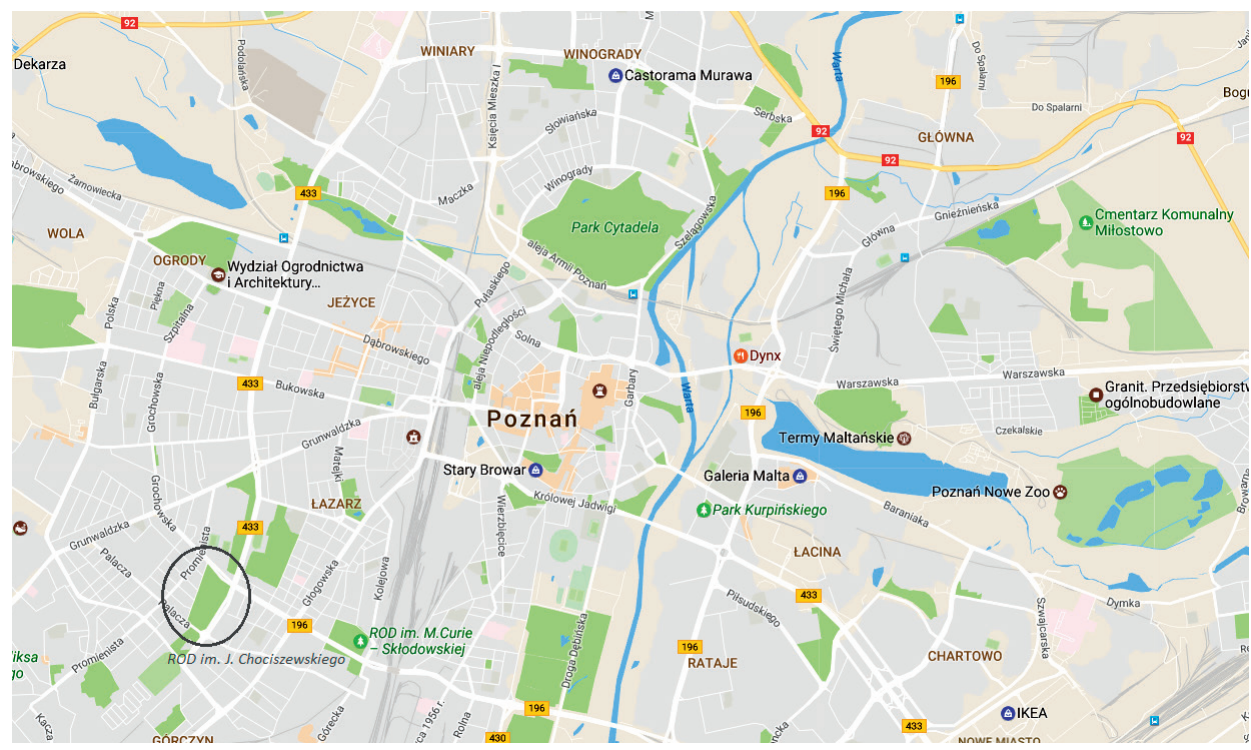

Rys. 3. Lokalizacja ROD im. J. Chociszewskiego w Poznaniu

Źródło: https://www.google.pl/maps (dostęp 12 listopada 2016).

tzw. fajerwerki, czyli zabawy „latowe”4. Towarzyszyły im różnego rodzaju gry, turnieje i loterie fantowe. Pozyskane dzięki nim środki finansowe przeznaczono na budowę świetlicy (Lisiewicz 2001).

W latach 60. XX w. powierzchnia ogrodu uległa zmniejszeniu w wyniku przebudowy skrzyżowania ulic Chociszewskiego i Arciszewskiego oraz budowy osiedla bloków mieszkaniowych. W 1976 r. prezesem została Stanisława Nowak. Dzięki jej staraniom udało się pozyskać dotację na przebudowę świetlicy, w której w późniejszym czasie organizowano wczasy dla seniorów i półkolonie dla dzieci (Lisiewicz 2001).

Na przełomie lat 60. i 70. w związku z rozbudową ul. Grochowskiej ogród pomniejszył się o kolejne działki, tym razem od strony ulic Arciszewskiego i Chociszewskiego. Rekompensatę stanowiły nowe działki wytyczone na terenie boiska klubu Korona. Obecnie ogród zajmuje powierzchnię ok. 9 ha i liczy 244 działki (rysunek 4). Na wielu działkach zachowały się oryginalne poniemieckie altanki. Większość z nich popada w ruinę (rysunek 5). Często obecni użytkownicy decydują się na ich wyburzanie i stawiają nowe altanki według własnego upodobania (rysunek 6). Niekiedy ma miejsce ich przebudowa, która zakłóca pierwotną myśl architektoniczną (rysunek 7). Jednak zdarzają się też przypadki doceniania oryginalności zabytkowych altanek, które poddawane są modernizacji uwydatniającej ich niepowtarzalny charakter (rysunek 8).

\footnotetext{
${ }^{4}$ Popularne na początku XX w. letnie zabawy plenerowe, najczęściej organizowane poza miastem, w otoczeniu zieleni, w ramach których odbywały się: koncerty, pochody, tańce, charytatywne loterie fantowe, turnieje, gry oraz popisy gimnastyczne.
} 


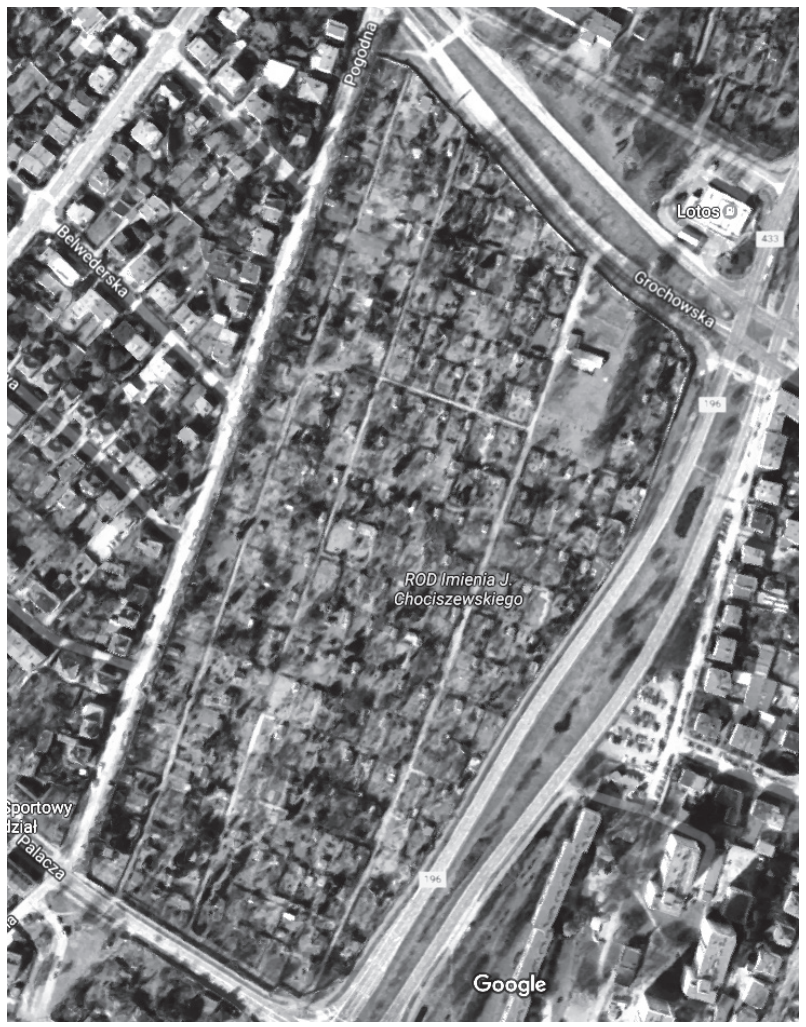

Rys. 4. Zdjęcie satelitarne ROD im. J. Chociszewskiego w Poznaniu Źródło: Jak w rysunku 3.

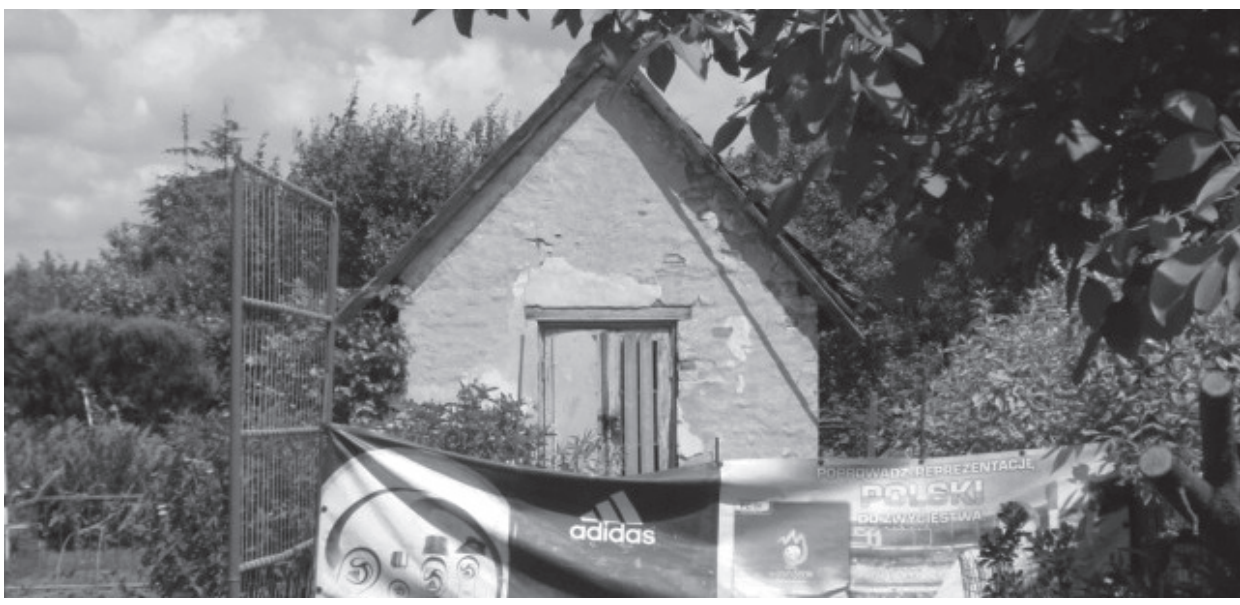

Rys. 5. Zrujnowana zabytkowa altana w ROD im. J. Chociszewskiego w Poznaniu Fot. D. Dymek. 


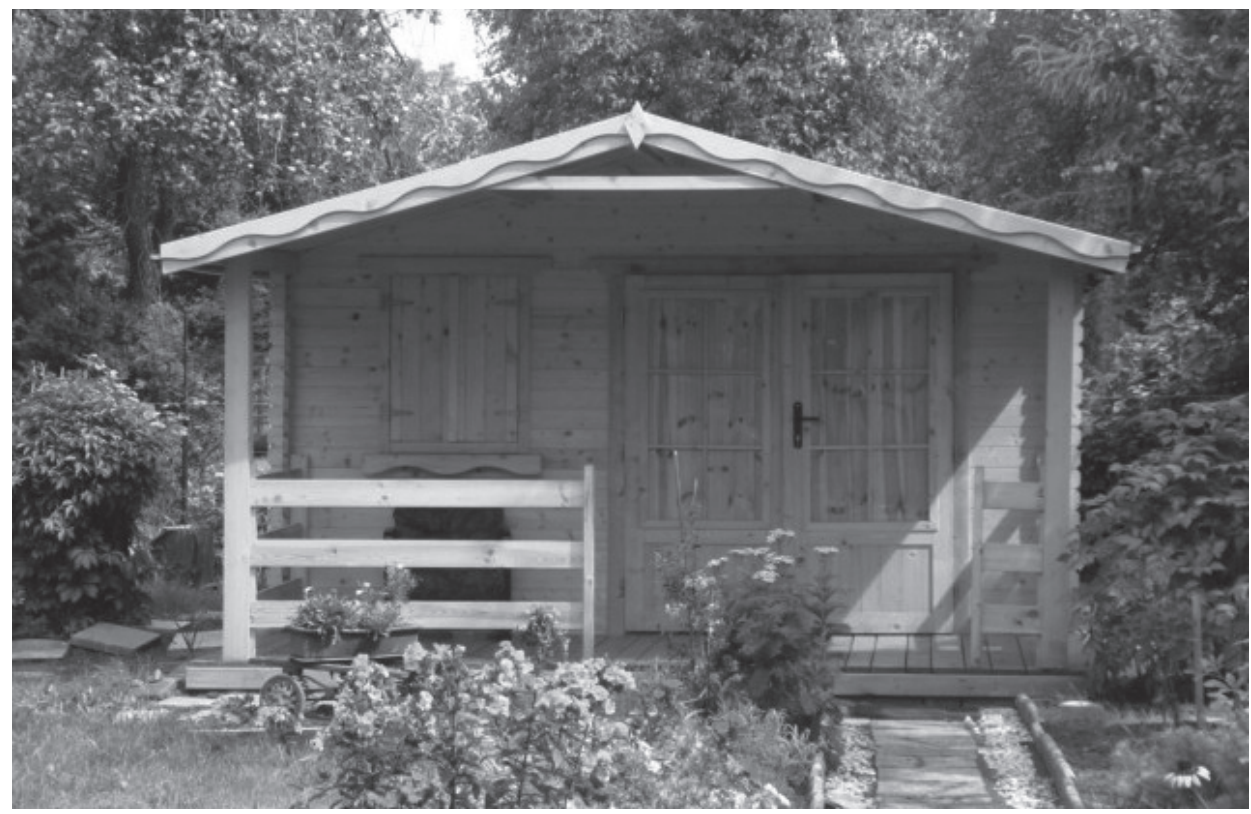

Rys. 6. Przykład nowej altanki w ROD im. J. Chociszewskiego w Poznaniu, która zastąpiła zabytkową Fot. D. Dymek.

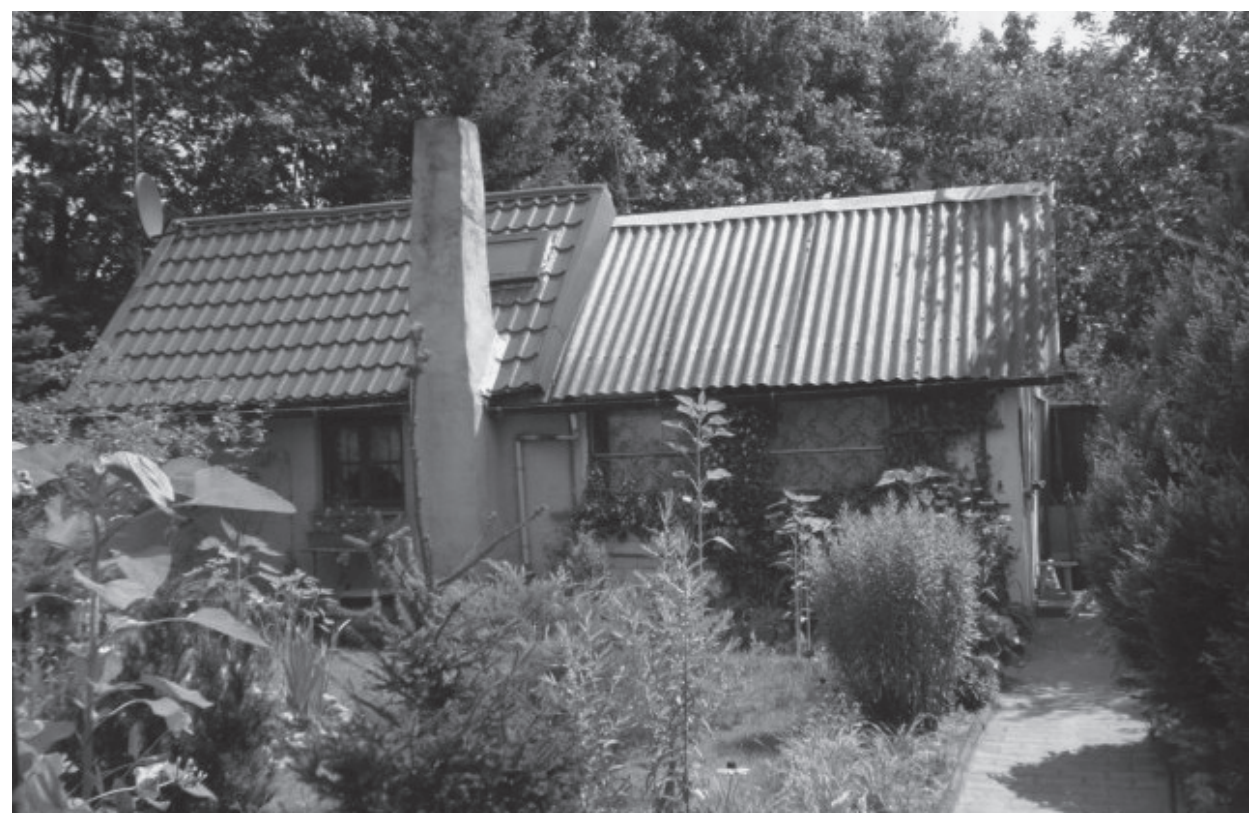

Rys. 7. Przykład całkowicie przebudowanej zabytkowej altany w ROD im. J. Chociszewskiego w Poznaniu Fot. D. Dymek. 


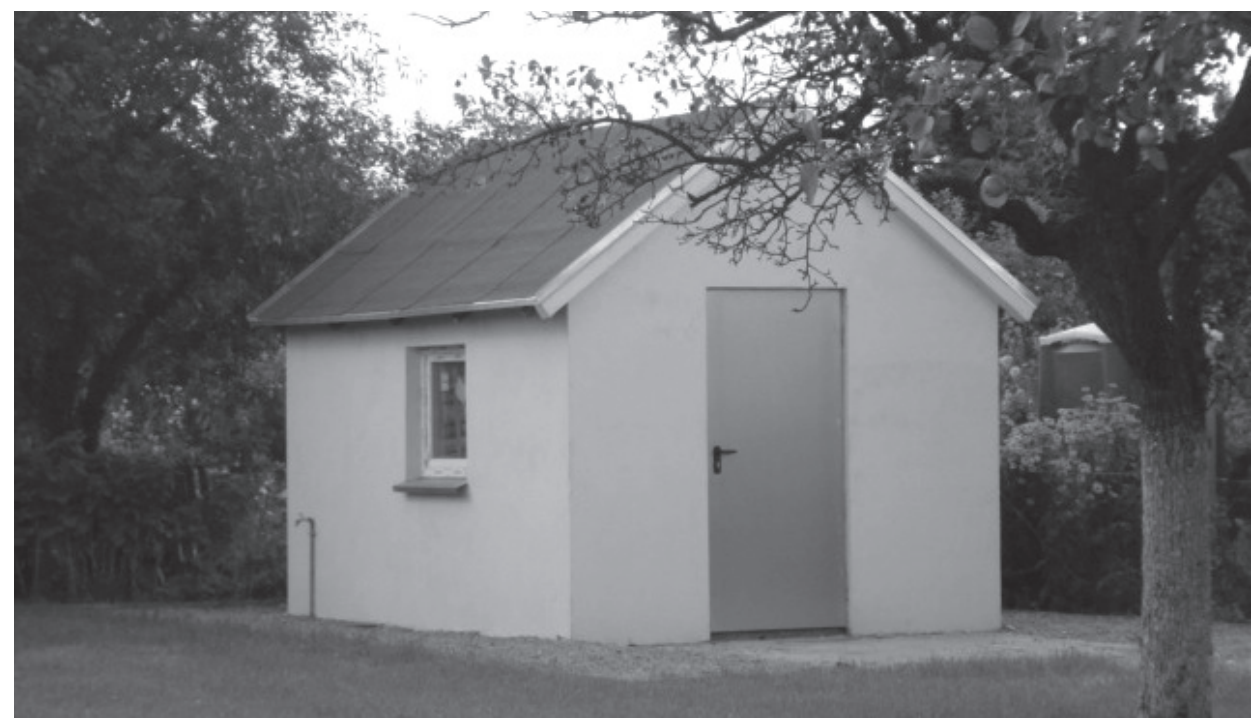

Rys. 8. Przykład zmodernizowanej zabytkowej altany w ROD im. J. Chociszewskiego w Poznaniu Fot. D. Dymek.

\section{Wyniki badań}

Wyniki inwentaryzacji 25 losowo wybranych działek ROD im. J. Chociszewskiego w Poznaniu wykazały duże zróżnicowanie w sposobie ich zagospodarowania. Powierzchnia badanych działek wahała się od $308 \mathrm{~m}^{2}$ do $528 \mathrm{~m}^{2}$, natomiast średnia powierzchnia działki to $379,36 \mathrm{~m}^{2}$. Największe różnice wśród elementów ożywionych wystąpiły w powierzchni przeznaczonej na uprawę warzyw. Współczynnik zmienności dla tej badanej cechy wyniósł 133,55. W pięciu z 25 badanych działek nie prowadzono żadnych upraw warzywniczych (działki nr 1, 4, 5, 12 i 20), podczas gdy trawnik występował w prawie wszystkich badanych obiektach poza jednym (działka nr 23). Rośliny ozdobne były obecne we wszystkich badanych działkach. Średnie powierzchnie wymienionych elementów wynoszą odpowiednio: $161,74 \mathrm{~m}^{2}, 35,56 \mathrm{~m}^{2}$ i 84,38 $\mathrm{m}^{2}$. Minimalna powierzchnia trawnika $\left(0 \mathrm{~m}^{2}\right)$ wystąpiła na działce $\mathrm{nr} 23$, na której jednocześnie zaobserwowano maksymalną powierzchnię przeznaczoną pod uprawę warzyw $\left(181 \mathrm{~m}^{2}\right)$. Z kolei największa powierzchnia trawnika $\left(352 \mathrm{~m}^{2}\right)$ dotyczy działki $\mathrm{nr} 20$, na której jednocześnie nie były prowadzone żadne uprawy warzywne. W przypadku upraw roślin ozdobnych obecnych na wszystkich badanych działkach minimalna powierzchnia wyniosła $14,5 \mathrm{~m}^{2}$, a maksymalna $174 \mathrm{~m}^{2}$. Aż 11 badanych obiektów posiadało powierzchnię upraw warzywnych poniżej $5 \%$ całkowitej powierzchni działki. W przypadku powierzchni zajmowanej przez trawnik aż w siedmiu z 25 badanych obiektów stanowił on ponad 50\% powierzchni całkowitej działki. Szczegółowe dane dotyczące powierzchni biologicznie czynnych działek przedstawia tabela nr 1 . 
Tabela 1

Zestawienie powierzchni poszczególnych powierzchni biologicznie czynnych działek w ROD im. J. Chociszewskiego w Poznaniu

\begin{tabular}{|c|c|c|c|c|c|}
\hline Nr działki & $\begin{array}{l}\text { Powierzchnia } \\
\text { całkowita* }\left[\mathrm{m}^{2}\right]\end{array}$ & Warzywa $\left[\mathrm{m}^{2}\right]$ & Owoce $\left[\mathrm{m}^{2}\right]$ & $\begin{array}{c}\text { Rośliny } \\
\text { ozdobne }\left[\mathrm{m}^{2}\right]\end{array}$ & Trawnik $\left[\mathrm{m}^{2}\right]$ \\
\hline 1 & 342 & 0 & 12,5 & 70 & 229,5 \\
\hline 2 & 356 & 29 & 11,5 & 128 & 84,5 \\
\hline 3 & 365 & 23 & 12 & 35,5 & 226 \\
\hline 4 & 363 & 0 & 15 & 131,5 & 135,5 \\
\hline 5 & 362 & 0 & 7 & 144 & 134 \\
\hline 6 & 391 & 1 & 8 & 57,5 & 266,5 \\
\hline 7 & 388 & 2 & 4,5 & 103 & 157 \\
\hline 8 & 327 & 14 & 15,5 & 18 & 200 \\
\hline 9 & 371 & 13,5 & 18 & 112,5 & 190 \\
\hline 10 & 365 & 22 & 48 & 129,5 & 102,5 \\
\hline 11 & 351 & 36 & 54 & 37,5 & 141 \\
\hline 12 & 381 & 0 & 47 & 86,5 & 148,5 \\
\hline 13 & 364 & 1,5 & 23 & 32 & 238,5 \\
\hline 14 & 326 & 71 & 28 & 41 & 135,5 \\
\hline 15 & 308 & 13,5 & 13 & 82 & 125,5 \\
\hline 16 & 484 & 16 & 58 & 118 & 235,5 \\
\hline 17 & 443 & 33,5 & 42 & 49 & 241 \\
\hline 18 & 343 & 30,5 & 30 & 153 & 77,5 \\
\hline 19 & 330 & 29 & 60 & 55,5 & 116,5 \\
\hline 20 & 480 & 0 & 20,5 & 70 & 352 \\
\hline 21 & 528 & 115 & 52 & 14,5 & 296,5 \\
\hline 22 & 336 & 116,5 & 54 & 45,5 & 27,5 \\
\hline 23 & 410 & 181 & 15,5 & 174 & 0 \\
\hline 24 & 330 & 117 & 60 & 107 & 15 \\
\hline 25 & 440 & 24 & 68 & 114,5 & 167,5 \\
\hline Średnia & 379,36 & 35,56 & 31,08 & 84,38 & 161,74 \\
\hline Minimum & 308 & 0 & 4,5 & 14,5 & 0 \\
\hline Maksimum & 528 & 181 & 68 & 174 & 352 \\
\hline $\begin{array}{l}\text { Odchylenie } \\
\text { standardowe }\end{array}$ & 55,84 & 47,49 & 20,67 & 45,36 & 87,17 \\
\hline $\begin{array}{l}\text { Współczynnik } \\
\text { zmienności }\end{array}$ & 14,72 & 133,55 & 66,51 & 53,76 & 53,9 \\
\hline
\end{tabular}

* Dane pozyskane z Zarządu ROD im. J. Chociszewskiego w Poznaniu.

Źródło: Opracowanie własne. 
Jeszcze większe zróżnicowanie otrzymanych wyników wystąpiło w przypadku powierzchni biologicznie czynnych badanych działek. Największy współczynnik zmienności dotyczy powierzchni zajmowanej przez nieużytki $(174,11)$, a najmniejszy komunikacji $(46,54)$. Każda z przebadanych działek posiadała altankę bądź budynek gospodarczy. Powierzchnia zabudowy wahała się od 7,5 $\mathrm{m}^{2}$ do $50 \mathrm{~m}^{2}$ przy średniej wynoszącej 18,34 $\mathrm{m}^{2}$. W przypadku elementów służących komunikacji tylko jedna z 25 badanych działek nie posiadała jakichkolwiek ścieżek utwardzonych bądź gruntowych. Maksymalna powierzchnia przeznaczona pod komunikację była równa $46,5 \mathrm{~m}^{2}$, a średnia dla tej zmiennej wynosiła $22,86 \mathrm{~m}^{2}$. W 14 z 25 obiektów badań nie zinwentaryzowano żadnych nieużytków. Największy udział nieużytków w powierzchni całkowitej działki zaobserwowano na działce $\mathrm{nr} 7-14,43 \%\left(56 \mathrm{~m}^{2}\right)$, a ich średnia powierzchnia wynosiła 8,96 $\mathrm{m}^{2}$. W 11 z 25 badanych obiektów nie stwierdzono obecności gratowiska. Maksymalna powierzchnia gratowiska występowała na działce $\mathrm{nr} 2\left(42,5 \mathrm{~m}^{2}\right)$, a średnia wynosiła $7,44 \mathrm{~m}^{2}$. W przypadku pozostałych elementów, tj. piaskownic, WC i innych, nie stwierdzono ich obecności w sześciu z 25 badanych obiektów. Największy udział tych elementów w powierzchni całkowitej działki zaobserwowano na działce nr 17 - 9,62\% $\left(33 \mathrm{~m}^{2}\right)$, a średnia dla tej zmiennej wynosiła 8,92 $\mathrm{m}^{2}$. Aż siedem działek nie posiadało zarówno nieużytków, jak i gratowiska (działki nr 1, 10, 14, 17, 18, 20, 24). Szczegółowe dane dotyczące elementów nieożywionych zagospodarowania działek przedstawia tabela nr 2 .

Tabela 2

Zestawienie powierzchni poszczególnych elementów nieożywionych zagospodarowania działek w ROD im. J. Chociszewskiego w Poznaniu

\begin{tabular}{|c|c|c|c|c|c|c|}
\hline Nr działki & $\begin{array}{c}\text { Powierzch- } \\
\text { nia całkowi- } \\
\text { ta* }\left[\mathrm{m}^{2}\right]\end{array}$ & $\begin{array}{c}\text { Zabudowa } \\
{\left[\mathrm{m}^{2}\right]}\end{array}$ & $\begin{array}{c}\text { Komunika- } \\
\text { cja }\left[\mathrm{m}^{2}\right]\end{array}$ & $\begin{array}{c}\text { Nieużytki } \\
{\left[\mathrm{m}^{2}\right]}\end{array}$ & $\begin{array}{c}\text { Gratowisko } \\
{\left[\mathrm{m}^{2}\right]}\end{array}$ & Inne $\left[\mathrm{m}^{2}\right]$ \\
\hline 1 & 342 & 14 & 16 & 0 & 0 & 0 \\
2 & 356 & 20 & 32,5 & 8 & 42,5 & 0 \\
3 & 365 & 22 & 32 & 0 & 8,5 & 4 \\
4 & 363 & 18 & 26 & 4 & 12 & 21 \\
5 & 362 & 14 & 27 & 31 & 5 & 0 \\
6 & 391 & 11 & 16 & 0 & 23 & 8 \\
7 & 388 & 13,5 & 46,5 & 56 & 5,5 & 0 \\
8 & 327 & 36 & 33 & 9 & 0 & 1,5 \\
9 & 371 & 20 & 9 & 4 & 0 & 4 \\
10 & 365 & 18 & 27 & 0 & 0 & 18 \\
11 & 351 & 9 & 31,5 & 19 & 7 & 16 \\
12 & 381 & 24,5 & 15,5 & 42 & 0 & 17 \\
13 & 364 & 7,5 & 29 & 0 & 8,5 & 24 \\
\hline
\end{tabular}


Tabela $2 \mathrm{~cd}$.

\begin{tabular}{|c|c|c|c|c|c|c|}
\hline Nr działki & $\begin{array}{l}\text { Powierzch- } \\
\text { nia całkowi- } \\
\mathrm{ta}^{*}\left[\mathrm{~m}^{2}\right]\end{array}$ & $\begin{array}{c}\text { Zabudowa } \\
\qquad\left[\mathrm{m}^{2}\right]\end{array}$ & $\begin{array}{c}\text { Komunika- } \\
\text { cja }\left[\mathrm{m}^{2}\right]\end{array}$ & $\begin{array}{c}\text { Nieużytki } \\
{\left[\mathrm{m}^{2}\right]}\end{array}$ & $\begin{array}{c}\text { Gratowisko } \\
{\left[\mathrm{m}^{2}\right]}\end{array}$ & Inne $\left[\mathrm{m}^{2}\right]$ \\
\hline 14 & 326 & 8 & 24,5 & 0 & 0 & 18 \\
\hline 15 & 308 & 13,5 & 22,5 & 36 & 0 & 2 \\
\hline 16 & 484 & 16 & 12,5 & 0 & 12 & 16 \\
\hline 17 & 443 & 36 & 8,5 & 0 & 0 & 33 \\
\hline 18 & 343 & 8 & 40,5 & 0 & 0 & 3,5 \\
\hline 19 & 330 & 18 & 16 & 0 & 19 & 16 \\
\hline 20 & 480 & 16 & 11,5 & 0 & 0 & 10 \\
\hline 21 & 528 & 30 & 0 & 12 & 8 & 0 \\
\hline 22 & 336 & 50 & 26,5 & 0 & 12 & 4 \\
\hline 23 & 410 & 11,5 & 19 & 3 & 5 & 1 \\
\hline 24 & 330 & 10 & 21 & 0 & 0 & 0 \\
\hline 25 & 440 & 14 & 28 & 0 & 18 & 6 \\
\hline Średnia & 379,36 & 18,34 & 22,86 & 8,96 & 7,44 & 8,92 \\
\hline Minimum & 308 & 7,5 & 0 & 0 & 0 & 0 \\
\hline Maksimum & 528 & 50 & 46,5 & 56 & 42,5 & 33 \\
\hline $\begin{array}{l}\text { Odchylenie } \\
\text { standardowe }\end{array}$ & 55,84 & 10,25 & 10,64 & 15,6 & 10,01 & 9,33 \\
\hline $\begin{array}{l}\text { Współczynnik } \\
\text { zmienności }\end{array}$ & 55,84 & 55,89 & 46,54 & 174,11 & 134,54 & 104,6 \\
\hline
\end{tabular}

* Dane pozyskane z Zarządu ROD im. J. Chociszewskiego w Poznaniu.

Źródło: Jak w tabeli 1.

\section{Podsumowanie}

Ogrody działkowe stanowią specyficzne tereny zieleni miejskiej, które pełnią szereg niezastąpionych funkcji korzystnie wpływających na jakość życia mieszkańców miast. Niewłaściwa estetyka działek ROD jest, obok ograniczonej dostępności, jedną z głównych przyczyn ich negatywnego wizerunku. Z biegiem lat wzrasta swoboda w sposobie zagospodarowania przestrzeni pojedynczych działek, która nie sprzyja poprawie ładu przestrzennego w ogrodach działkowych. Przeprowadzone badania w ROD im. Józefa Chociszewskiego w Poznaniu dowiodły wyraźnej tendencji do zanikania tradycyjnej funkcji użytkowej działek, która polegała na prowadzeniu upraw owocowo-warzywnych. Grządki warzywne i kwatery sadownicze coraz częściej zastępowane są przez trawniki, które służą wypoczynkowi i rekreacji. W wielu zinwentaryzowanych trawnikach można było dostrzec pozostałości obrzeży dawnych grządek warzywnych, 
które stanowią poparcie dla stawianej wyżej tezy. Z kolei spotykane obecnie uprawy w ROD mają charakter eksperymentalno-hobbystyczny, który wynika z zamiłowania działkowców do uprawy ziemi i pielęgnowania roślin. Taka zmiana funkcji kulturowych miejskich ogrodów działkowych wynika z dwóch przyczyn. Pierwszą z nich jest dużo większa dostępność tanich warzyw i owoców, która sprawia, że ich uprawa na własny użytek nie tylko jest nieopłacalna, ale najzwyczajniej nie jest konieczna. Z kolei wzrost znaczenia rekreacyjnego miejskich ogrodów działkowych ma związek z: wciąż niedostateczną ilością terenów zieleni miejskiej, ubogą ofertą aktywności i przestrzeni dla seniorów, którzy mimo zwiększającego się zainteresowania działkami przez osoby młode nadal stanowią najliczniejszą grupę użytkowników działek, oraz pogarszającymi się warunkami życia w mieście. Intensywne natężenie ruchu drogowego, spaliny, hałas, gęsta zabudowa, mała dostępność zieleni urządzonej - to stałe elementy, z jakimi na co dzień zmagają się mieszkańcy dużych aglomeracji miejskich. Dzięki znajdującej się w ogrodach zieleni, ale także kwitnącemu życiu sąsiedzkiemu, obecnie działki pełnią rolę swoistych zielonych enklaw pośród „miejskiej dżungli”.

\section{Wnioski}

Analiza aktów prawnych dotyczących ogrodów działkowych wykazała, że wraz z kolejnymi ustawami działkowcy mają coraz większą swobodę w zagospodarowaniu swoich działek, które znacznie lepiej odpowiadają ich aktualnym potrzebom.

Inwentaryzacja wybranych działek ROD im. Józefa Chociszewskiego w Poznaniu świadczy o zanikaniu funkcji użytkowych działek na rzecz rekreacji.

Zwiększenie maksymalnej dopuszczalnej powierzchni altan działkowych przyczynia się do niekontrolowanego rozbudowywania lub wyburzania istniejących zabytkowych altan, które stanowią cenny wyróżnik kompozycji przestrzennej w ROD im. Józefa Chociszewskiego w Poznaniu.

\section{Bibliografia}

Billert A., 2013, Kultura a rozwój społeczny i przestrzenny miast. Doświadczenia niemieckie, Kongres Ruchów Miejskich, http://kongresruchowmiejskich.pl/wp-content/uploads/2013/04/ABillert.pdf (dostęp 12 listopada 2016).

Długozima A., 2012, Wzornictwo ogrodów działkowych, [w:] Wzornictwo ogrodowe, red. J. Rylke, Wydawnictwo Sztuka Ogrodu Sztuka Krajobrazu, Warszawa.

Dymek D., 2014, Rodzinne ogrody działkowe w świetle nowej ustawy, [w:] Kierunki zmian terenów zieleni w miastach, red. M. Kosmala, PZIiTS Oddział w Toruniu, Toruń.

Dymek D., 2015, Ogrody działkowe a jakość życia, [w:] Biocity, t. 1, red. F. Górski, M. Łaskarzewska-Średzińska, Fundacja Wydziału Architektury Politechniki Warszawskiej, Warszawa.

Groeger L., 2016, Zagospodarowanie miejskiej przestrzeni mieszkaniowej w aspekcie potrzeb społeczności lokalnych, „Acta Universitatis Lodziensis. Folia Geographica Socio-Oeconomica” z. 24.

Kosmala M., Kamińska M., 2013, O działkach i parkach - działkowcy Torunia $i$ Warszawy, [w:] Ogrody działkowe w miastach - bariera czy wartość?, red. M. Kosmala, PZIiTS Oddział w Toruniu, Torun. 
Lisiewicz I., 2001, Rys historyczny od 1923 r. na podstawie protokołów i materiałów z rodzinnych archiwów działkowców i ludzkiej pamięci, http://www.barcinek.fora.pl/spory-o-rod-w-kraju-budowa-nowych-ogrodow-ogrody-dzialkowe-w-innych-krajach,88/historia-90-letniego-rod-im-j-chociszewskiego-wp-niu,976.html (dostęp 28 listopada 2016).

Mierzejewska L., 2001, Tereny zielone w strukturze przestrzennej miasta Poznania, Wydawnictwo Poznańskiego Towarzystwa Przyjaciół Nauk, Poznań.

Parysek J., 1995, Rola samorząu terytorialnego w rozwoju lokalnym, [w:] Rozwój lokalny: zagospodarowanie przestrzenne i nisze atrakcyjności gospodarczej, red. J. Parysek, KPZK PAN, Warszawa.

Pawlikowska-Piechotka A., 2010, Tradycja ogrodów działkowych w Polsce, Novae Res - Wydawnictwo Innowacyjne, Gdynia.

Regulamin pracowniczego ogrodu działkowego z dnia 29 października $1981 \mathrm{r}$.

Regulamin rodzinnego ogrodu działkowego z dnia 7 kwietnia $2004 \mathrm{r}$.

Regulamin rodzinnego ogrodu działkowego z dnia 21 lutego $2014 \mathrm{r}$.

Romanowski H., 2012, Uwagi o architekturze ogrodów działkowych, „Czasopismo Techniczne” z. 19.

Roskosz J.Z., 1968, Pracownicze ogrody działkowe, Wydawnictwo Związkowe CRZZ, Warszawa.

Szczepańska M., Krzyżaniak M., Świerk D., Urbański P., 2016, Rodzinne ogrody działkowe jako element zielonej infrastruktury na terenie aglomeracji poznańskiej, „Studia Miejskie” t. 22.

Szczęsny M., Kimic K., 2012, Możliwości adaptacji terenów ogrodów działkowych na obiekty ogólnodostępne na przykładzie Rodzinnego Ogrodu Działkowego przy kanale Gocławskim w Warszawie, "Czasopismo Techniczne" z. 30.

Szkup R., 2013, Użytkowanie rodzinnych ogrodów działkowych (ROD) przez społeczność wielkomiejską, przykład Łodzi, Wydawnictwo Uniwersytetu Łódzkiego, Łódź.

Ustawa z dnia 9 marca 1949 r. o pracowniczych ogrodach działkowych, Dz.U. z 1949 r. Nr 18, poz. 117.

Ustawa z dnia 6 maja 1981 r. o pracowniczych ogrodach działkowych, Dz.U. z 1996 r. Nr 85, poz. 390.

Ustawa z dnia 8 lipca 2005 r. o rodzinnych ogrodach działkowych, Dz.U. z 2005 r. Nr 169, poz. 1419.

Ustawa z dnia 13 grudnia 2013 r. o rodzinnych ogrodach działkowych, Dz.U. z 2014 r., poz. 40.

Wilczyński S., 1927, Ogródki działkowe jako zagadnienie społeczne, Drukarnia św. Wojciecha, Poznań.

Worytkiewicz P., 2012, Armaty w cieniu pomidorów, [w:] Dzieło-działka, Muzeum Etnograficzne im. Seweryna Udzieli w Krakowie, Kraków. 